\title{
Paleoseismology and slip rate of the Conway Segment of the Hope Fault at Greenburn Stream, South Island, New Zealand
}

\author{
Robert Langridge $\left({ }^{1}\right)$, Jocelyn Campbell $\left({ }^{2}\right)$, Nigel Hill $\left({ }^{1}\right)$, Verne Pere $\left({ }^{2}\right)$, James Pope $\left(^{2}\right)$, Jarg Pettinga $\left({ }^{2}\right)$, \\ Beatriz Estrada $\left(^{2}\right)$ and Kelvin Berryman $\left(^{1}\right)$ \\ ${ }^{1}{ }^{1}$ Institute of Geological and Nuclear Sciences, Lower Hutt, New Zealand \\ $\left.{ }^{2}\right)$ Department of Geological Sciences, University of Canterbury, Christchurch, New Zealand
}

\begin{abstract}
The Conway Segment of the dextral-slip Hope Fault is one of the fastest slipping fault segments along New Zealand's plate boundary, but has not ruptured co-seismically in the historic period and little paleoseismic data exist to constrain its large earthquake record. Two paleoseismic trenches were opened adjacent to Greenburn Stream near Kaikoura for the 2001 ILP Paleoseismology Conference. Both trenches were excavated into deposits ponded against an uphill-facing shutter scarp. Trench 1, dug through a cobbly soil and surface deposit was dominated by a thick fan/fluvial sequence that was radiocarbon dated at $4409 \pm 60 \mathrm{C}^{14}$ years BP (4844-5288 cal years BP) at the base of the trench. This trench exhibited evidence of complex deformation from many paleoseismic events. The most recent earthquakes are difficult to constrain due to a lack of cover stratigraphy on the fan deposits. However, the modern soil appears to be faulted and is covered by cobbles with a weathering rind-derived age of $220 \pm 60$ years. Trench 2 , dug $\sim 50 \mathrm{~m}$ to the west has an expanded sequence of the younger cover deposits. Paleoseismic event horizons have been recognised from the combined evidence of upwardterminating faults, offset and mismatched units, a sandblow deposit, and abrupt landscape change shown by the burial of paleosol surfaces that form the event horizons. Two paleosols underlying the modern soil are clearly faulted by two separate rupture events. A dome of sand interpreted as a liquefaction sandblow deposit overlies the lower paleosol (event horizon). Both paleosols are overlain by metre-thick debris deposits, interpreted as earthquake-induced rock avalanches that cascaded off the hillslope following $M_{w} 7+$ events. Four radiocarbon dates place some constraints on the timing of the three recent surface-rupturing events. The youngest and lowest date is $548 \pm 60 \mathrm{C}^{14}$ years BP $(504-656$ cal years BP) and occurs below the lower paleosol. It constrains the maximum duration of time in which the last 2 earthquake events occurred to be 545 years (1295-1840 A.D.). This is consistent with the average Recurrence Interval (RI) of 180-310 years that we determine using two independent paths. The soil record indicates that each event is separated by a significant period of time, comparable to the calculated RI. The most recent event is constrained between ca. 1780 A.D. \pm 60 years, taking into account the dates from these trenches, a weathering rind age, and from stratigraphic correlation at the site. Event III probably occurred before 1220 A.D. A maximum dextral slip rate of $23 \pm 4 \mathrm{~mm} / \mathrm{yr}$ is calculated from the minimum fan age and the offset/deflection of a stream channel along the shutter ridge. In concert with the estimate of single event displacement (5-6 m), these results show that the Conway Segment of the Hope Fault is fast-slipping and has ruptured regularly as a result of large earthquakes prior to the European colonisation of New Zealand.
\end{abstract}

Key words Hope Fault - Kaikoura - Conway Segment - New Zealand - paleoseismicity - neotectonics - slip rate - recurrence - NZMS 260 sheet 031

Mailing address: Dr. Robert Langridge, Institute of Geological and Nuclear Sciences, P.O. Box 30-368, Lower Hutt, New Zealand; e-mail: r.langridge@gns.cri.nz

\section{Introduction}

The Hope Fault is a $230 \mathrm{~km}$ long system of dextral-slip faults at the southwestern edge of the Marlborough Fault Zone (MFZ), that can be traced from the Alpine Fault to the northeast coast of South Island near Kaikoura (Freund, 
1971). Deformation across the MFZ accommodates the oblique convergence of the AustralianPacific plate margin in Northern South Island (fig. 1), marking the transition from the westfacing Hikurangi subduction margin to the east- facing Alpine Fault and Puysegur subduction margin (Berryman et al., 1992; Holt and Haines, 1995). The MFZ comprises four main strike-slip faults with subsidiary oblique-slip faults (e.g. Kekerengu Fault) occurring at its northeastern

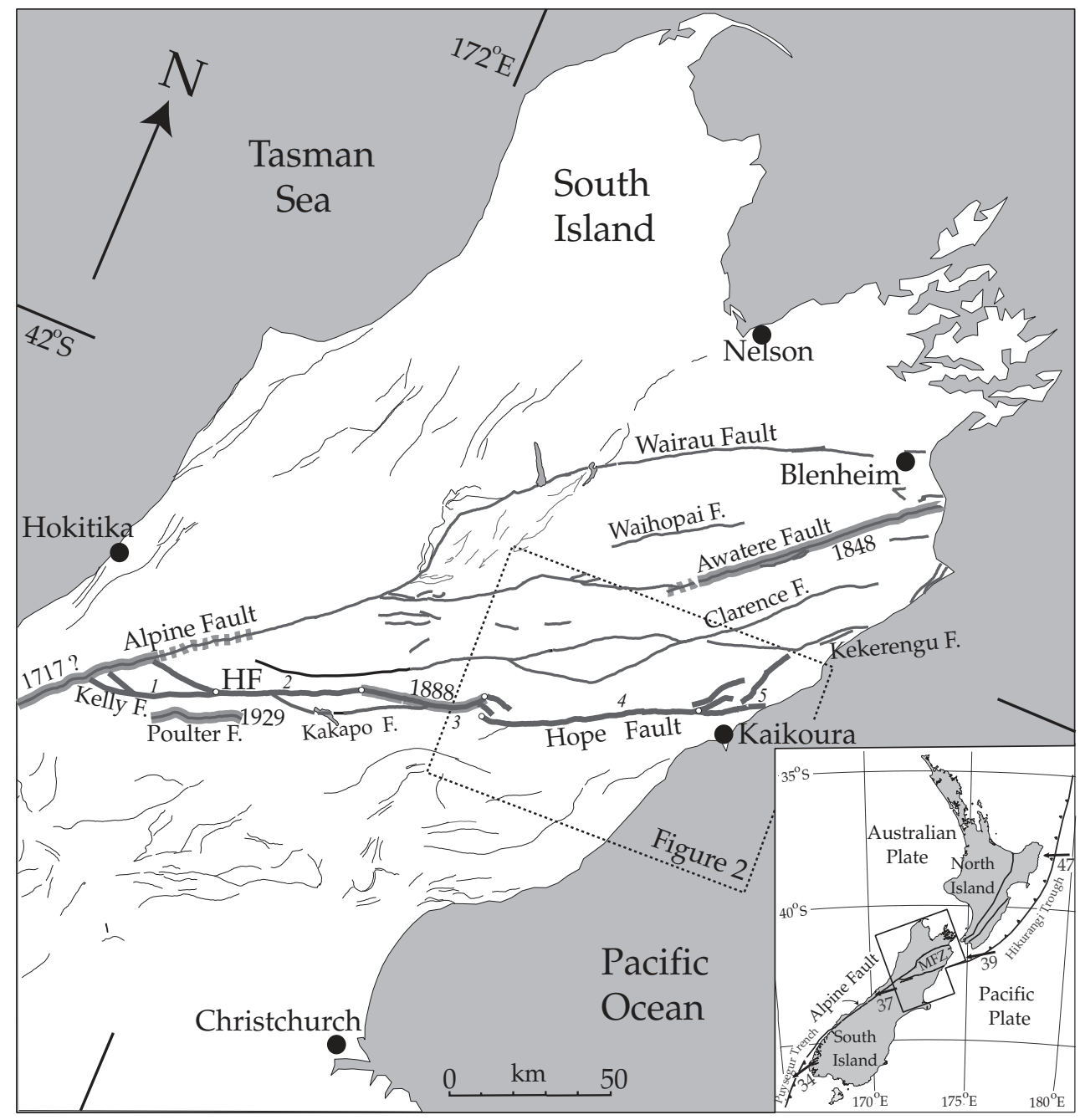

Fig. 1. Location of the Hope Fault in the Marlborough Fault Zone (MFZ) (bold lines), Northern South Island. The Hope Fault System is shown boldest and fault segments are numbered in italics (1 - Kelly Fault; 2 - Hurunui section; 3 - Hope River Segment; 4 - Conway Segment, and 5 - Seaward Segment), their boundaries being marked by open circles. Surface fault ruptures, e.g., 1888 North Canterbury earthquake, are shown as grey bands. Inset: New Zealand plate boundary including Alpine Fault, MFZ and Hikurangi Trough. Nuvel-1 directions (arrows) and plate rates relative to Australian Plate (in mm/yr) after DeMets et al. (1994). 
end (Van Dissen and Yeats, 1991). Those four faults account for a large proportion of the plate boundary motion at their location, where almost complete locking occurs between the subducting (Pacific) plate and overriding (Australian) plate. From northwest to southeast, these faults are the Wairau, Awatere, Clarence, and Hope Faults (Lensen, 1968; Campbell, 1973; Kieckhefer, 1979; Yeats and Berryman, 1987; Van Dissen, 1989; McCalpin, 1996). These faults generally have higher slip rates as one progresses southeast across the MFZ. The eastern Hope Fault (Conway Segment) has the highest Holocene slip rate (Bull, 1991; McMorran, 1991; Knuepfer, 1992; Pope, 1994) and geodetic rate (Bibby, 1976; Bourne et al., 1998) for faults within the MFZ. However, the Conway Segment has only a modest level of seismicity and no record of surface-rupturing earthquakes within New Zealand's short historic period (Anderson et al., 1993; Reyners and Cowan, 1993; Anderson and Webb, 1994). Indeed, within the MFZ since 1840 A.D. only the eastern Awatere Fault (1848) and central Hope Fault (Hope River Segment - 1888) have ruptured co-seismically (McKay, 1890; Cowan, 1991; Grapes et al., 1998). In addition, the prehistoric (paleoearthquake) record of the Conway Segment of the Hope Fault is not well understood at this time.

The 2001 ILP Conference on Paleoseismology offered us the unique opportunity to study and present results from our second fastest slipping onland fault in an international forum. Data from two new trenches excavated, logged and dated in conjunction with the conference program allow us to estimate: i) the age of the three most recent earthquake events and their bearing on previous studies, and ii) a new dextral slip rate for the Conway Segment of the Hope Fault from the Greenburn Stream site.

\section{The Hope Fault and Conway Segment}

The Hope Fault has been traced from its branching junction with the Alpine Fault south of Hokitika (fig. 1), northeast to the coast north of Kaikoura (Freund, 1971; Van Dissen, 1989) and into the offshore shelf region (Barnes and Audru, 1999). Important early onshore studies relate to the reconnaissance of the 1888 North Canterbury earthquake, recognition of strikeslip displacement (McKay, 1890), and subsequent mapping of the fault system in its entirety (Freund, 1971; Hardy and Wellman, 1984). The Hope Fault has been the subject of numerous recent neotectonic and structural studies, many emanating from the University of Canterbury (e.g., Cowan, 1989, 1990; Van Dissen, 1989; Bull, 1991; McMorran, 1991; Cowan and McGlone, 1991; Pope, 1994; Wood et al., 1994; Simpson, 1995; Eusden et al., 2000).

Based on tectonic geomorphology and the record of the 1888 event, the Hope Fault can be divided into a number of geometrically-defined segments or sections (fig. 1), namely the Kelly Fault, and the Hurunui, Hope River, Conway, and Seaward segments (see Van Dissen, 1989; Cowan and McGlone, 1991; Simpson, 1995; Pettinga et al., 1998, 2001; Langridge, 2003). This paper focuses on the Conway Segment of the Hope Fault, a $70 \mathrm{~km}$ section from the Kowhai River to the Hanmer Basin (fig. 2), emphasising results from a trench site adjacent to Greenburn Stream. East of the Kowhai River, the Conway Segment splays into a number of dextral and transpressive features, including the Fyffe Fault, Kowhai Fault and Jordan Thrust (Van Dissen and Yeats, 1991) (fig. 3). At its western end the Conway Segment begins from the Hanmer Basin, an extensional step-over or pull-apart in the Hope Fault System, which is also the northeastern termination of the 1888 surface faulting event (McKay, 1890; Freund, 1971; Cowan, 1991; Wood et al., 1994).

The Conway Segment is characterised by a relatively continuous linear trace striking about $\mathrm{N} 73^{\circ} \mathrm{E}$ and has a slip rate of $18-35 \mathrm{~mm} / \mathrm{yr}$ based on offset alluvial features (Freund, 1971; Van Dissen, 1989; Bull, 1991; McMorran, 1991; Knuepfer, 1992; Pope, 1994). The Conway Segment bounds the southern rangefront of the Seaward Kaikoura, Hawk and Amuri ranges (figs. 2, 3). Oblique compression across the Hope Fault System is responsible for $>2 \mathrm{~km}$ of topography observed in these ranges (fig. 3). Where exposed, the fault dips steeply to the NW at $\sim 70^{\circ}$ (Van Dissen, 1989; McMorran, 


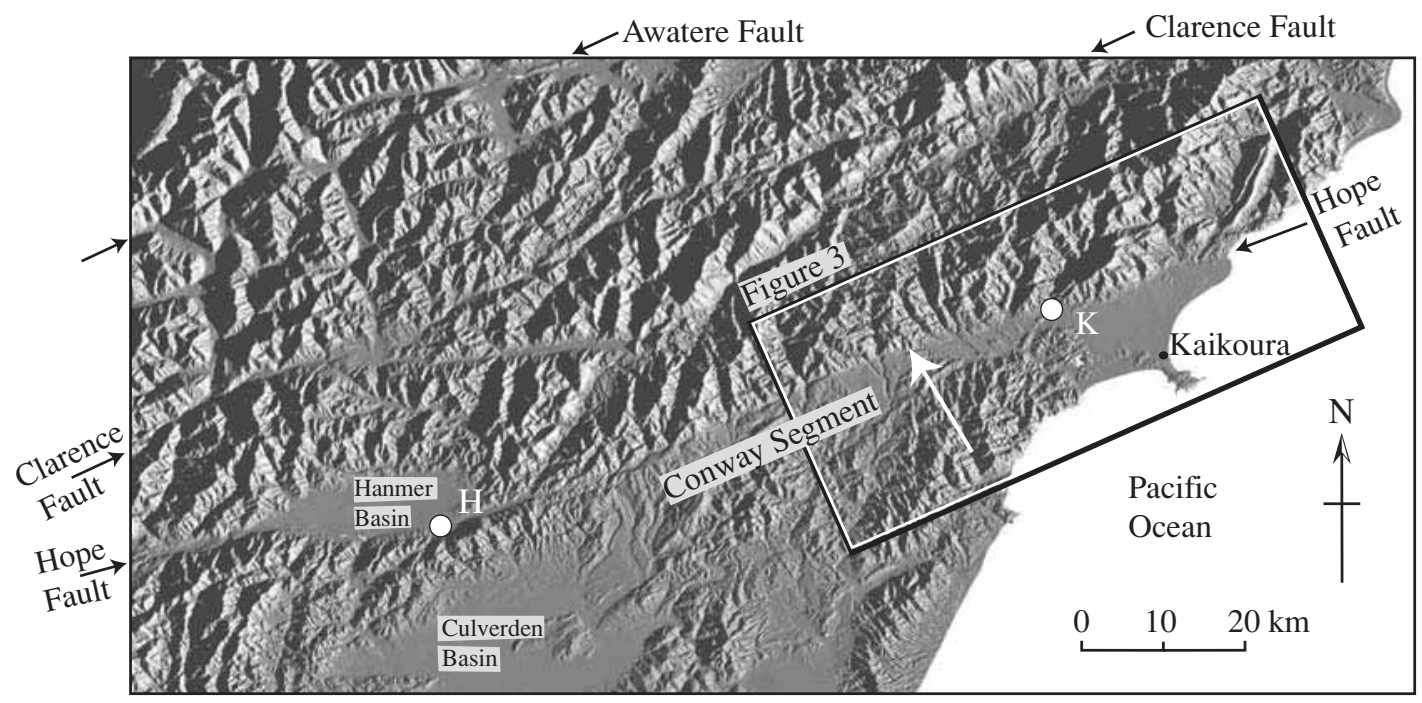

Fig. 2. Digital Terrain Model of the southeast MFZ, illuminated from the southeast. Major active faults are shown by arrows and delineated by the rangefronts and valleys. In the west, the Hope Fault System consists of ENE-trending strike-slip sections separated by the Hanmer Basin extensional stepover, and passes east into oblique-contractional faults near the coast. The Conway Segment is shown between the Hanmer Basin and Kowhai River (K), marked by two white circles. The Greenburn Stream site is shown by a white arrow; Hossack Saddle $(\mathrm{H})$.

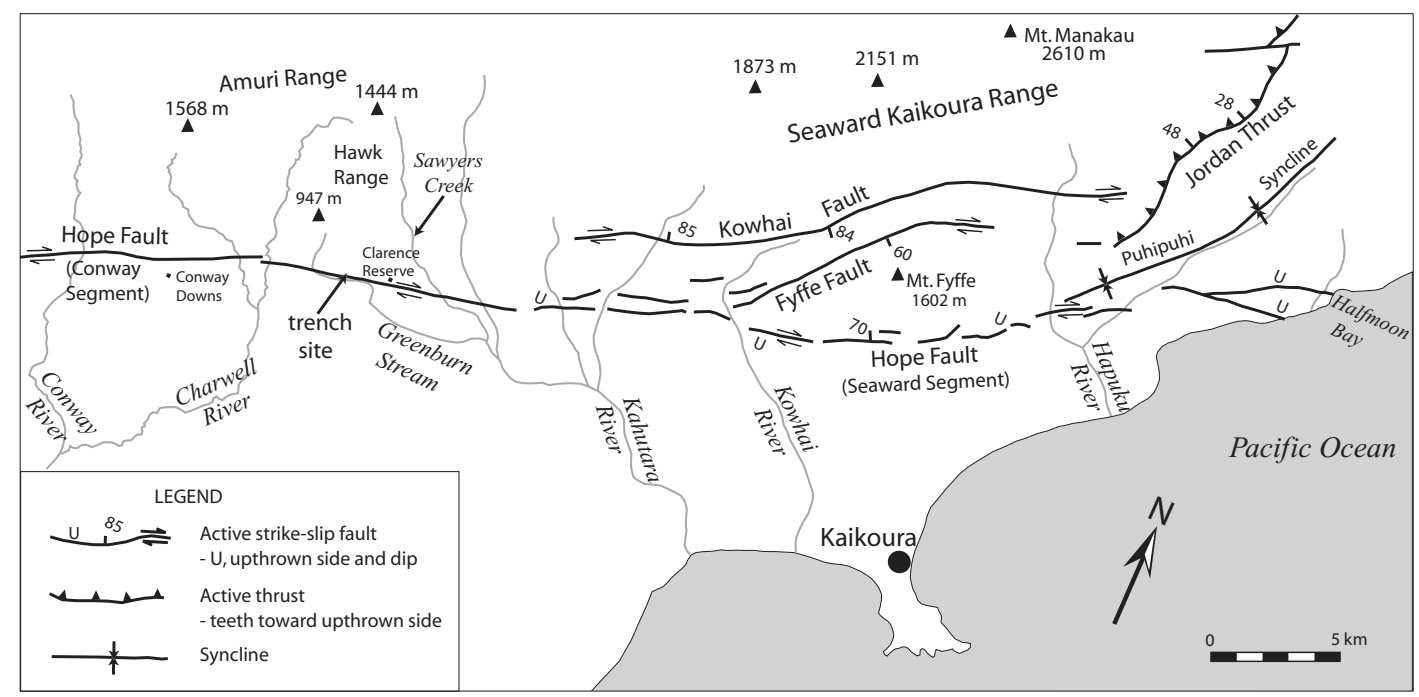

Fig. 3. Structure of the eastern Hope Fault and location of the Greenburn Stream trench site (modified after Campbell, 2001). The Conway Segment passes east into the Seaward Segment east of Kowhai River, and the Mt. Fyffe and Kowhai Faults. The trench site is adjacent to Greenburn Stream. 
1991). Although no large earthquakes have ruptured the Conway Segment historically (last $\sim 160$ years), lichenometric studies suggest that the Conway Segment was recently ruptured twice by large seismic events $\left(M_{w} 7+\right)$ in 1768 A.D. and in the 1830's, the decade preceding the advent of initial European colonisation (Bull, 1998; Bull and Brandon, 1998).

Paleoseismic studies have been conducted along this segment of the Hope Fault by McMorran (1991) and by Pope (1994) near Greenburn Stream. McMorran was able to demonstrate a Holocene slip rate of $18 \pm 8 \mathrm{~mm} / \mathrm{yr}$ but could not determine the age of any paleo-earthquake events. Pope (1994) trenched a small sag pond at Clarence Reserve (fig. 3) and was able to recognise and date three paleoearthquake events. None of these events are believed young enough to represent the most recent surface-rupturing event. Therefore, considerable scope still remained to undertake paleoseismic and slip rate studies along the Conway Segment.

\section{The Greenburn Stream site}

Near Greenburn Stream the Hope Fault has a clear geomorphic trace in aerial photographs and on the ground (fig. 4). The fault scarp at Greenburn Stream forms a linear trace, characterised mainly by an uphill-facing scarp located near the base of the southern, faceted rangefront of the Hawk Range. Several deeplyincised southward draining streams cross the fault trace (fig. 3). Two paleoseismic trenches were opened at a site $\sim 700 \mathrm{~m}$ upstream from the Highway 70 bridge over Greenburn Stream adjacent to a tributary stream, here informally referred to as «Urquhart Stream» (NZMS 260 O31/423678), shown in fig. 5. The trenches were excavated across a ridge or «shutter scarp», that has been dextrally displaced by the fault. The scarp is cored by sheared basement greywacke sandstones (Torlesse Group) that formerly created a barrier to stream flow. A fan aggraded against this ridge and it is clear that an

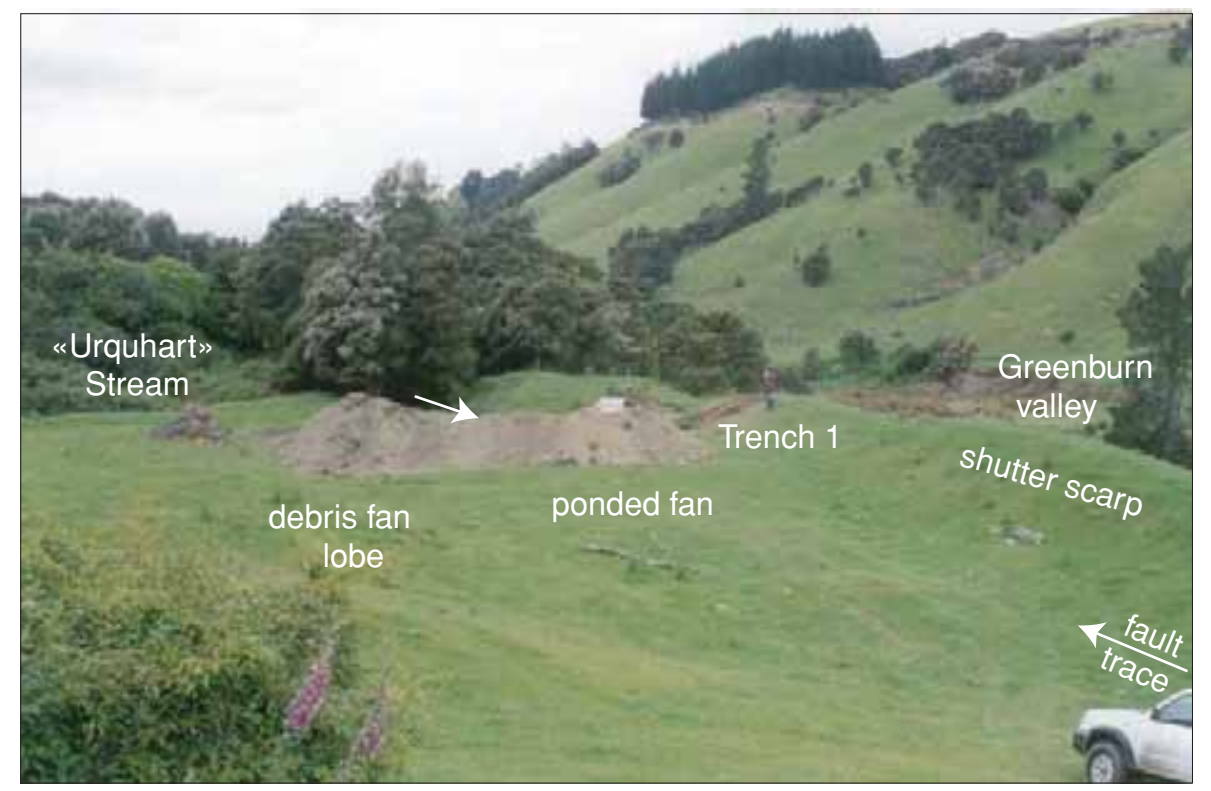

Fig. 4. The Greenburn Stream site with vehicle for scale. View to the east shows Trench 1 excavated through the shutter scarp and into the ponded alluvial fan surface. The site is elevated above modern «Urquhart Stream» and Greenburn valley. Drainage at the site was from left to right. Recent incision by Urquhart Stream has abandoned this surface. 


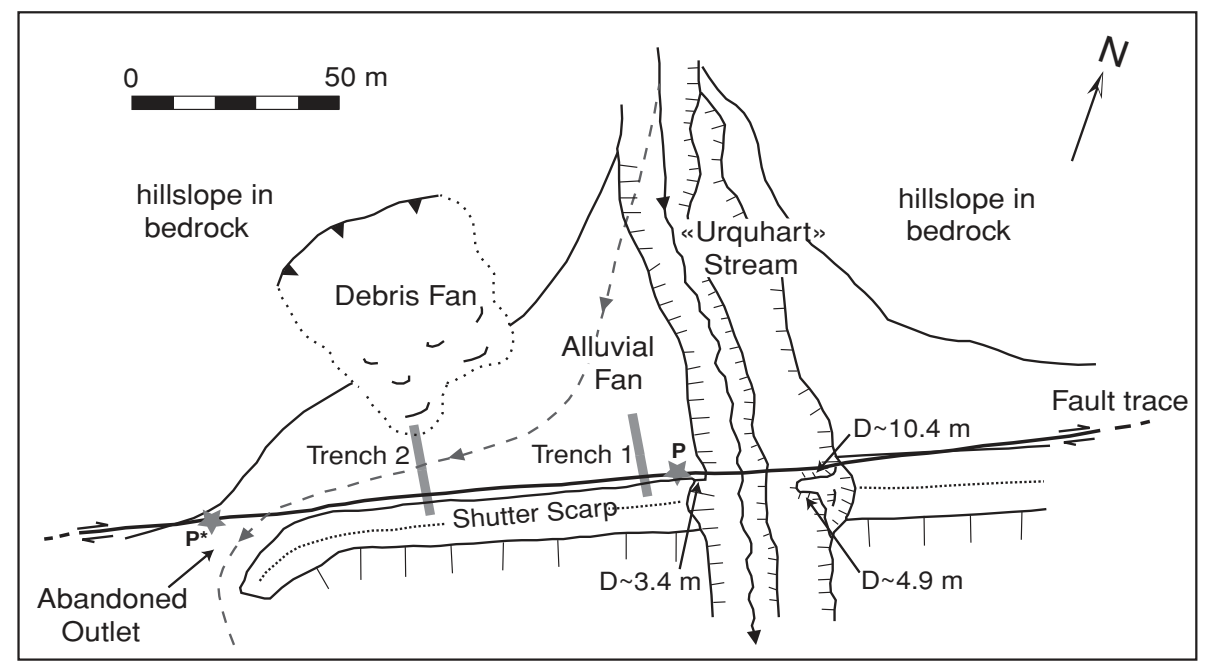

Fig. 5. Simplified geomorphic sketch of the trench site (modified after Pope, 1994). Modern incised Urquhart Stream crosses the fault but was formerly deflected dextrally and drained through the abandoned outlet. The fault deflection $\mathbf{P}$ to $\mathbf{P}^{*}$ is marked by stars. Inferred measured single event dextral (D) displacement values (in metres) are shown. Trench 2 clips deposits of the landslide lobe at its northern end as shown on log.

older channel was dextrally deflected around the western end of the ridge. This fan and channel were later abandoned when Urquhart Stream incised through the bedrock shutter ridge. Scattered, angular blocks of greywacke that remain on the top surface of the abandoned fan yield a weathering rind age of $\sim 220$ years (Pope, 1994). Trench 1 was dug through the scarp and fan surface, while Trench 2 was excavated $\sim 50 \mathrm{~m}$ further to the west (fig. 5). Immediately north of the fault at Trench 2 is a small debris fan and scar that had potential as a datable, event-capping and shaking-induced deposit.

In detail, the shutter scarp has a sinuous, almost en échelon stepping scarp morphology. The style of the scarp (tectonic geomorphology) is influenced by the transpressive nature of the Conway Segment (Campbell, 2001). The fault dips $60-70^{\circ}$ to the north and the ranges have an up-to-the-north sense of topography, as does the uphill-facing shutter scarp. The Torlesse bedrock coring the shutter ridge is highly sheared with overthrust relations in exposures along Urquhart Stream, and a $15 \mathrm{~cm}$ wide gouge (pug) zone, cor- responding to the Hope Fault, is also exposed in its channel.

A series of dextral displacement estimates were measured from geomorphic features by Pope (1994) between Greenburn and Sawyers Creek. These measurements range from 3.4 to $31 \mathrm{~m}$ dextral displacement and reflect the likelihood of multiple events accumulating offset on older features. The average of nine Single Event Displacement (SED) measures in this area is 5-6 m (Pope, 1994). Three displacement measures were made adjacent to the trenches within the modern, incised banks of Urquhart Stream. These values are 3.4, $4.9 \pm 0.2$, and $10.4 \pm 0.2 \mathrm{~m}$. Pope concluded that the higher value was derived from two displacement events, while the lower value was considered to be a minimum due to erosional trimming of the stream bank at the fault.

\section{Trench 1}

Trench 1 (T1) was located $\sim 10 \mathrm{~m}$ from the west bank of Urquhart Stream, excavated 
to a length of $\sim 17 \mathrm{~m}$ and benched (fig. 4). The scarp height there, relative to the fan surface, is $\sim 1.6 \mathrm{~m}$ and the total exposure from the highest point on the shutter scarp to lowest point in the trench is $\sim 5 \mathrm{~m}$. The site was chosen with several hypotheses about the geomorphology and subsurface materials in mind, including: i) the presence of a thick fan aggradation sequence deposited against the shutter ridge; ii) post-fan abandonment deposits against the scarp, including the surficial cobble deposit, that may contain charcoal and evidence for the most recent earthquakes, and iii) a cross-sectional view through the scarp at the location of an en échelon step, that may give insights into the structure of such features. Only the east wall of the trench was logged at the time of the ILP conference and is presented in detail for this paper. However, the west wall of T1 was mapped in January 2002. The west wall comprised similar units to the east wall, though the thicknesses were expanded, and therefore the sequence did not extend as far back in time.

\subsection{Stratigraphy}

The stratigraphy in Trench 1 was consistent with the three surface hypotheses above, made prior to excavation. The stratigraphy is summarised below and in fig. 6. A more detailed description of the stratigraphy can be supplied by the co-authors. The six major packages recognised in T1 are the: Scarp; Lower, Middle and Upper South Fan; North Fan, and Channel Packages. These packages are overlain at the ground surface by the modern topsoil. The packages have stratigraphic, unconformity, and fault relations separating them. The Scarp Package is composed mainly of intensely sheared Torlesse greywacke sandstone. In places a dark red to grey clay (fault gouge) is interlayered with the sheared bedrock. In addition, two interbedded scarp units composed of weathered and fragmental greywacke-derived clasts are considered sedimentary in origin. In all probability, the Scarp Package has a complex deformation history with interleaving and overthrust

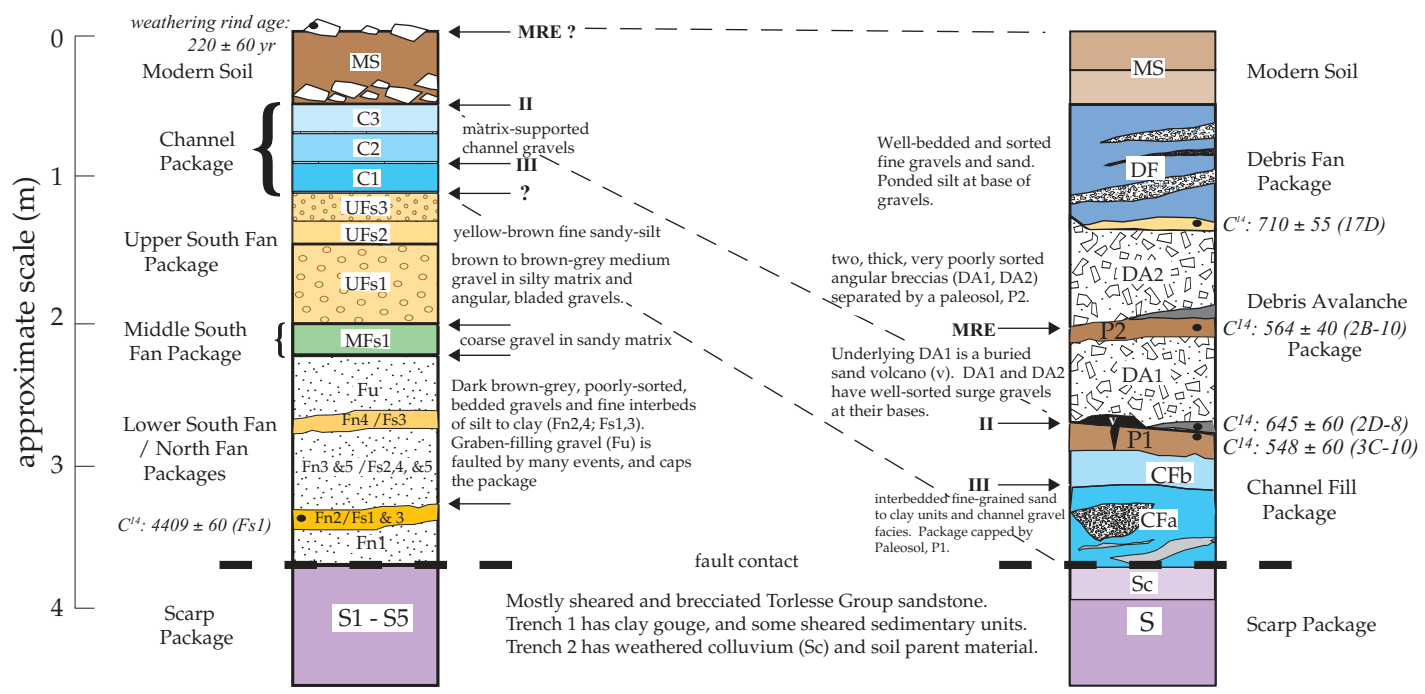

Fig. 6. Generalised stratigraphy and age of deposits from the Greenburn trenches. The youngest cover deposits at Trench 1 (Channel Package and modern soil) increase in thickness across the trench to the west and may be laterally contiguous with a thicker, expanded section in Trench 2 (dashed lines). Radiocarbon and surface ages are attached to the column. Horizontal arrows point to earthquake event horizons. 
Robert Langridge, Jocelyn Campbell, Nigel Hill, Verne Pere, James Pope, Jarg Pettinga, Beatriz Estrada and Kelvin Berryman
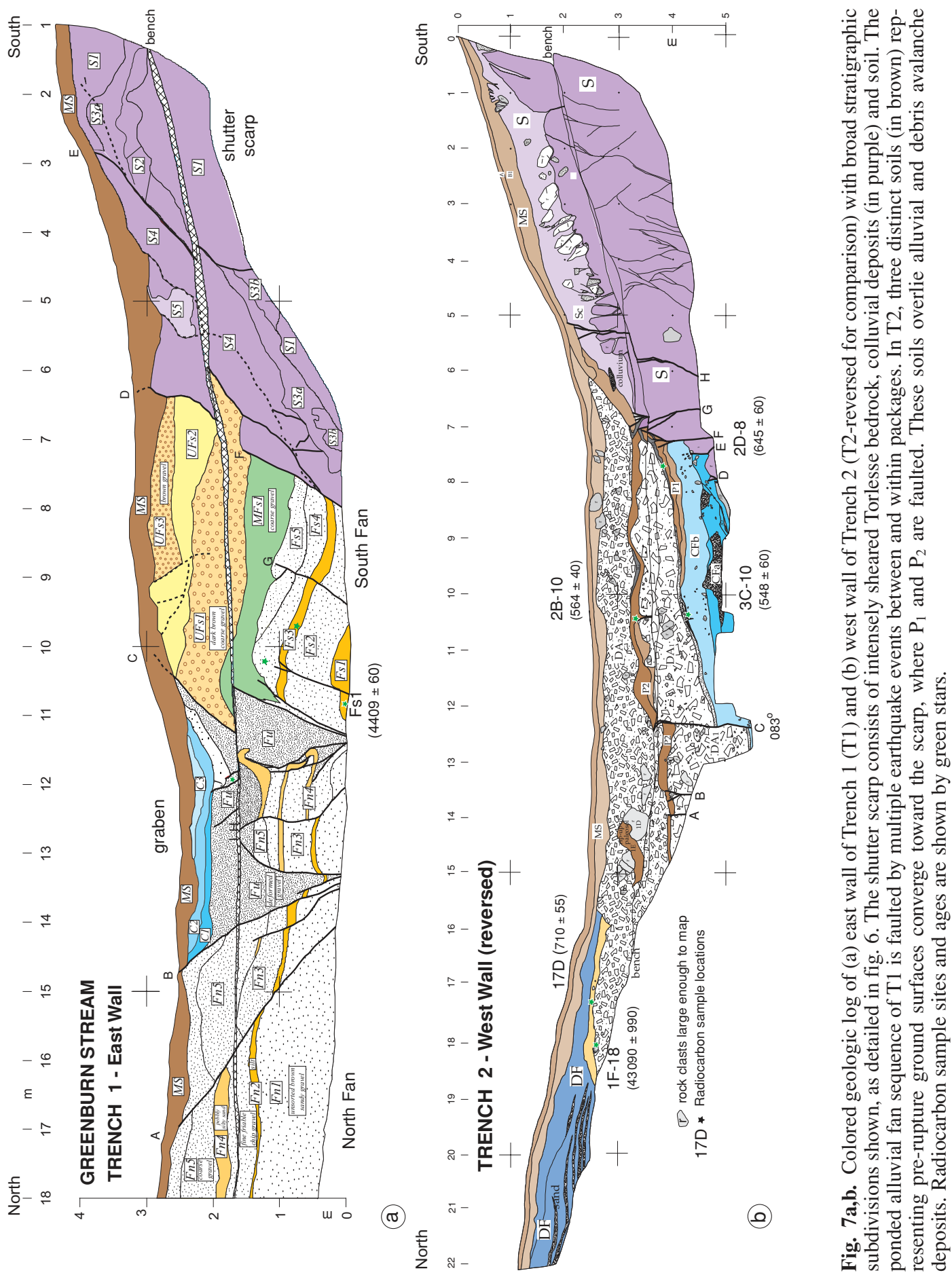
relations likely. All other packages onlap or are faulted against the Scarp Package.

The South Fan refers to three packages of distinctive deposits between the scarp and intense graben faulting, all being separated by unconformities. The Lower South Fan Package (Fs) comprises five units dominated by poorly sorted, bedded gravels with angular to subangular sandstone clasts in a clay matrix. Bands of weakly indurated fine sand to clay act as marker horizons separating distinct gravel units. Fine-grained charcoal was located in several of these fine units. A single radiocarbon date from a sandy silt bed (Fs1) near the base of the trench (fig. 7a) yielded an age of $4409 \pm 60 \mathrm{C}^{14}$ years BP (table I). We use this age below to develop a slip rate and recurrence data from this site.

The Middle South Fan Package consists of only one unit $\left(\mathrm{MFs}_{1}\right)$, an unconformity-bound coarse gravel deposit. The Upper South Fan Package consists of three units. The main body of this package consists of coarse, brown gravel within a silty matrix. The capping unit is a dark brown-grey gravel of angular bladed clasts of up to $10 \mathrm{~cm}$ diameter in a sandy matrix. This unit has accumulated $\sim 30 \mathrm{~cm}$ of apparent vertical displacement across it against the scarp deposits during recent displacement events.

The North Fan Package (Fn) comprises six units. The exposed lower half of this package consists of dark brown-grey, poorly sorted greywacke gravel (Fn1). Above this are interbedded gravel and silt-clay units. These units are capped by and faulted against undifferentiated, deformed $(\mathrm{Fu})$ gravels that fill a graben-shaped fea- ture in the middle of this trench. There is a general correspondence between the North Fan and Lower South Fan packages in this trench. However, it is not possible to directly match gravel or silt facies from north to south along the trench wall. The South and North Fan Packages are consistent with fan aggradation related to the former course of Urquhart Stream.

The uppermost package is named the Channel Package (C). It consists of three units $\left(\mathrm{C}_{1}-\mathrm{C}_{3}\right)$ of channel gravels that fine upwards overall, i.e. they show evidence for decreasing stream power up-section. The channel deposits appear to correspond to a scarp-parallel drainage system. Package C merges upward into the modern topsoil (MS), which has formed on an angular cobble deposit (fig. 6). Other angular blocks of greywacke up to $15 \mathrm{~cm}$ occur on the surface of MS. These blocks have thin weathering rinds that yield young geomorphic ages ( $\sim 220$ years) for the clasts and soil surface (Pope, 1994). For reasons discussed below, we apply an uncertainty of \pm 60 years to this age determination. As shown in fig. 6 and described below, the $\mathrm{C}$ Package probably corresponds to the Channel Fill (CF) Package of Trench 2, while the MS in $\mathrm{T} 1$ corresponds to all deposits above $\mathrm{CF}$ in Trench 2.

\subsection{Faulting}

The $\log$ of Trench 1 is shown in fig. 7a. The bench affects the geometry of units and continuity of faults whose strike is oblique to the

Table I. Summary of radiocarbon dating results from the Greenburn trenches, Eastern Hope Fault.

\begin{tabular}{|c|c|c|c|c|c|c|c|}
\hline $\begin{array}{l}\text { Location/ } \\
\text { description }\end{array}$ & $\begin{array}{c}\text { Sample } \\
\text { I.D. }\end{array}$ & $\begin{array}{c}\text { Sample } \\
\text { type }\end{array}$ & $\begin{array}{l}\text { Lab } \\
\text { number }\end{array}$ & $\begin{array}{l}{ }^{13} \mathrm{C} /{ }^{12} \mathrm{C} \\
\text { (per mil) }\end{array}$ & $\begin{array}{c}\text { Radiocarbon } \\
\text { age (years BP) }\end{array}$ & \multicolumn{2}{|c|}{ 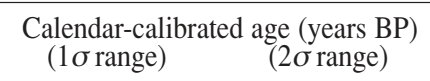 } \\
\hline $\begin{array}{l}\text { Trench } 1 \text { fan silt } \\
\text { Trench } 2\end{array}$ & Fs1 & $\mathrm{CH}$ & NZA 14707 & -25.1 & $4409 \pm 60$ & $4869-5050$ & $4844-5$ \\
\hline below liquefaction sand & $3 \mathrm{C}-10$ & $\mathrm{CH}$ & NZA 14708 & -25.5 & $548 \pm 60$ & $520-559 ; 598-629$ & $504-656$ \\
\hline at base of DF gravels & $1 \mathrm{~F}-18$ & $\mathrm{CH}$ & NZA 14709 & -21.5 & $43090 \pm 990$ & - & - \\
\hline surge gravel of DA1 & 2D-8 & $\mathrm{CH}$ & NZA 15137 & -25.13 & $645 \pm 60$ & $556-603 ; 624-660$ & $543-671$ \\
\hline within paleosol, P2 & $2 \mathrm{~B}-10$ & $\mathrm{CH}$ & NZA 15136 & -25.91 & $564 \pm 40$ & $533-558 ; 599-628$ & $517-649$ \\
\hline ponded silt above DA2 & 17D & $\mathrm{CH}$ & NZA 14925 & -25.29 & $710 \pm 55$ & $651-679$ & $555-603 ; 623-731$ \\
\hline
\end{tabular}

All radiocarbon analyses are AMS and were performed by Rafter Radiocarbon Laboratory, IGNS Ltd., Lower Hutt, NZ. Locations co-ordinates are from NZMS 260 Series Map O31/423678. Sample location abbreviations come from fig. 6. Samples all consist of charcoal, CH. Ages are calibrated using INTCAL98-14C of Stuiver et al. (1998). 
geomorphic trace. T1 has a complex deformation history with many high- to low-angle faults dipping both to the north and south. In addition to the dominant dextral motion, the fan of faults in Trench 1 between metres 6 to 17 gives the appearance of a significant normal component of motion behind the shutter scarp (fig. 7a). This style of young faulting must occur as a response (in covering fill deposits) to the fault dip and dextral-oblique (transpressional) nature of the rangefront and shutter scarp faulting. The Scarp Package is intensely sheared (cataclastically deformed) and does not yield any useful paleoseismic data. However, the stepped nature of faulting within the scarp is consistent with the observation of an en échelon character to the shutter scarp. If we consider the age of the fill units against the scarp shown by sample Fs1 $(\sim 5000$ years, table I), nature of the well developed fault zone, and a conservative estimate of the range of earthquake recurrence, it is clear that at least 10 earthquakes are responsible for the deformation visible in Trench 1 . This implies a considerable amount of strike-slip separation on the sedimentary packages, explaining why it has been difficult to match units of the North and South Fan packages across the zone of faulting.

The fan of faults in T1 cut units to several levels within the stratigraphy. Evidence for faulting during the most recent surface-rupturing earthquake event (MRE) comes from faults $\mathrm{B}, \mathrm{C}$ and $\mathrm{D}$ that appear to terminate upward in the modern soil and clearly displace the unit contacts below the soil. We believe that the modern soil and the ground surface are faulted. At this time we have no radiocarbon dates to bracket the timing of this event in T1. The width of the zone of surface faulting in T1 during the MRE may be $\sim 8 \mathrm{~m}$.

We also observe evidence for the 2nd and 3rd events in Trench 1 . The cobble deposit that forms the parent material of MS was faulted in the MRE. Additionally, it appears to drape over faults (A and D) which were active during the second event. Channel $\mathrm{C}_{1}$ and is possibly dragfaulted on fault $\mathrm{B}$. The occupation of channels $\mathrm{C}_{1}$ to $\mathrm{C}_{3}$ parallel to the scarp, and faults bounding them, imply that faulting has occurred be- tween fan abandonment (incision of Urquhart Stream) and the present. Fault J clearly faults and juxtaposes deposits of $\mathrm{C}_{1}$. This probably occurred during Event III.

Evidence for previous events comes from several other faults and unconformities in the trench. For example, faults $\mathrm{H}$ and $\mathrm{I}$ cut the North Fan Package, but not the paleosol on Unit $\mathrm{Fu}$ or the Channel Package above it, and therefore, probably represent events that occurred prior to the current incision of Urquhart Stream. Additionally, fault $\mathrm{G}$ cuts the Lower South Fan Package only, while fault $\mathrm{F}$ cuts up higher, to at least the base of the Upper South Fan Package. None of these events can be temporally-constrained at this time.

In summary, due to a lack of useful datable material and complex deformation over a period of at least 5000 years (table I) it is difficult to separate out the number, or individual timing, of events in Trench 1. However, this trench has provided useful information concerning the styles of sedimentation and deformation over this period and the uppermost deposits and deformation form a strong partner to the paleoseismic record observed in Trench 2 .

\section{Trench 2}

Trench 2 (T2) was excavated $\sim 50 \mathrm{~m}$ west of Trench 1 across the shutter scarp at a bearing of $002^{\circ}$ near the outlet of the abandoned fan drainage (fig. 5). The trench was sited in the lowest part of the basin behind the shutter scarp (fig. 8), where we suspected there would be a ponded finer-grained sequence of units. The benched trench is $22 \mathrm{~m}$ long and has up to $4.5 \mathrm{~m}$ relief from the top of the scarp to the bottom of the trench (fig. 7b). Only the west wall of this trench was logged as the units and deformation were both very similar across the trench.

The trench was excavated here in order to intercept: i) the highest point of the bedrock scarp and therefore scarp-derived colluvia; ii) the toe of a landslide expressed in the geomorphology at the north end of the trench (fig. 5), and iii) a hypothesised thicker sequence of young fault zone ponded alluvial deposits that 


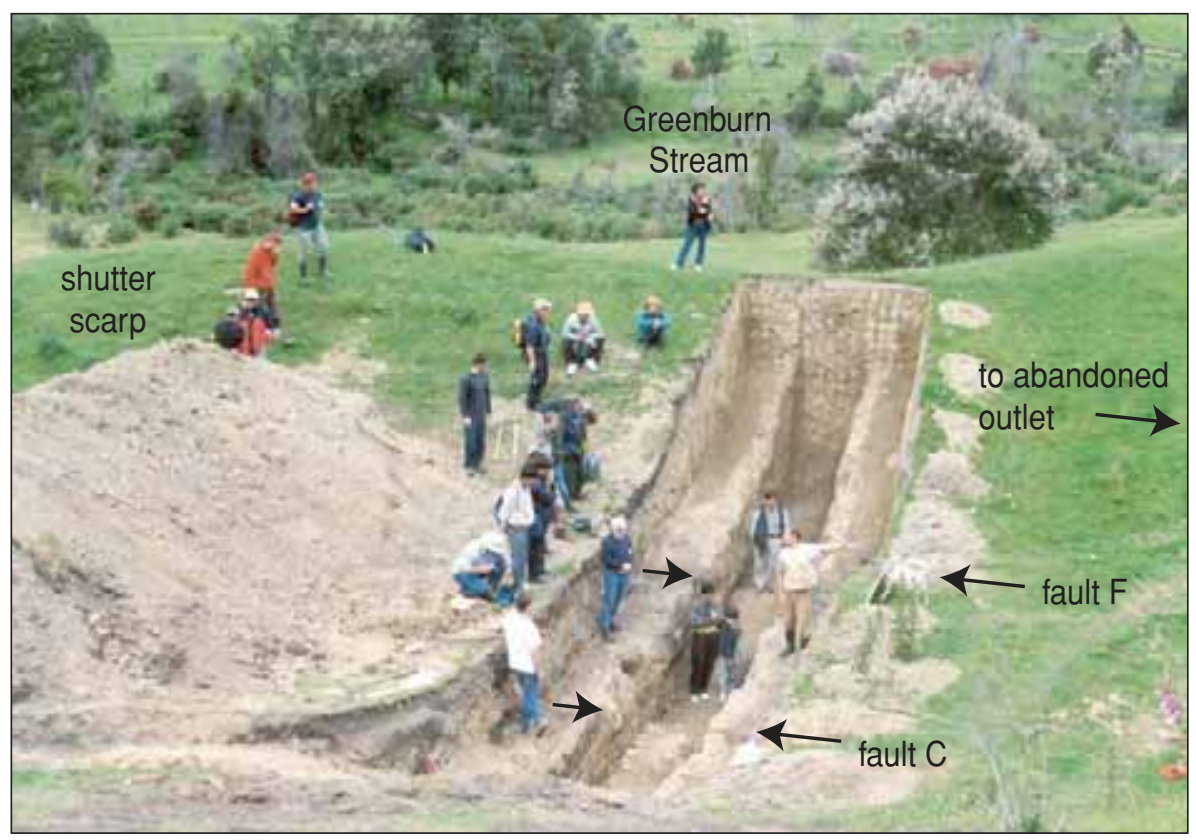

Fig. 8. Trench 2 at the time of the 2001 ILP Meeting. The picture is taken looking southeast from a debris fan above the trench toward Greenburn Stream. The trench reaches from the apex of the shutter scarp to the toe of the debris fan. Two main zones of recent fault rupture (arrows) were identified cutting the buried stratigraphy.

would be useful in the distinction of discreet paleo-events.

\subsection{Stratigraphy}

Figure 7a,b shows both the stratigraphic and structural comparisons between the two trenches. The stratigraphic sequence of $\mathrm{T} 2$ is generally younger, less complex, and less deformed than that of Trench 1, with four packages overlain by the modern soil profile (fig. 6). Deposition patterns range from gradual, as in the development of soils and ponded fills, to channel-filling alluvial deposition, to punctuated as in the deposition of debris flows or avalanches. The Scarp Package (S) again consists mostly of highly sheared Torlesse sandstone, which is intensely fractured to chip-sized clasts and is cut by numerous minor shears. Above the bedrock is a $40-80 \mathrm{~cm}$ thick zone of large sand- stone blocks in a weathered matrix of gravel to clay-sized fragments (fig. 9a-d). This unit represents an active soil and colluvial pair forming on the fault scarp.

The stratigraphically-lowest onlap package is the Channel Fill Package (CF), which consists of two main units. The lower unit $\left(\mathrm{CF}_{\mathrm{a}}\right)$ contains two channel gravels interbedded with fine-grained deposits. This is overlain by channel-free yellow-brown silty clay which grades upward into a wedge-shaped paleosol (Paleosol 1) that includes pieces of charcoal. Paleosol 1 $\left(\mathrm{P}_{1}\right)$ thins and pinches out to the north becoming an organic silt, implying a facies change into a subaqueous pond environment (fig. 10). We interpret the change from gravel lenses to fine fill and soil to correspond to the timing of abandonment of the deflected Urquhart Stream channel.

The Debris Avalanche Package is dominated by two, $\sim 1 \mathrm{~m}$ thick, very poorly sorted, clast-supported angular greywacke sandstone 


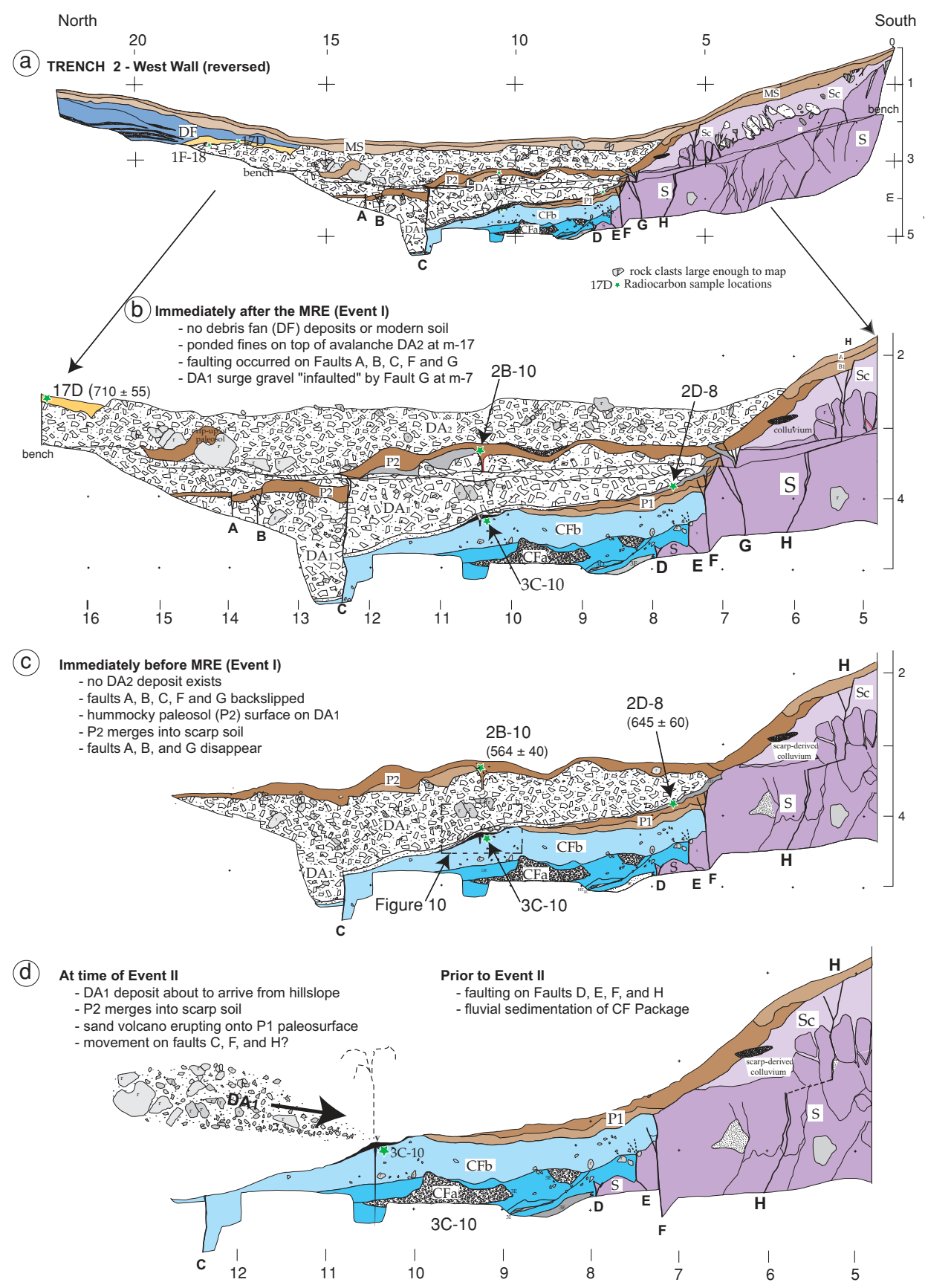

Fig. 9a-d. Sequence and explanation of retro-deformed logs of the west wall of Trench 2: a) the trench as logged; b) through d) show progressive unstripping of stratigraphy and removal of deformation. The area of fig. 10 , including sandblow deposit (in black), is shown by a dashed box at metre- 10 . 


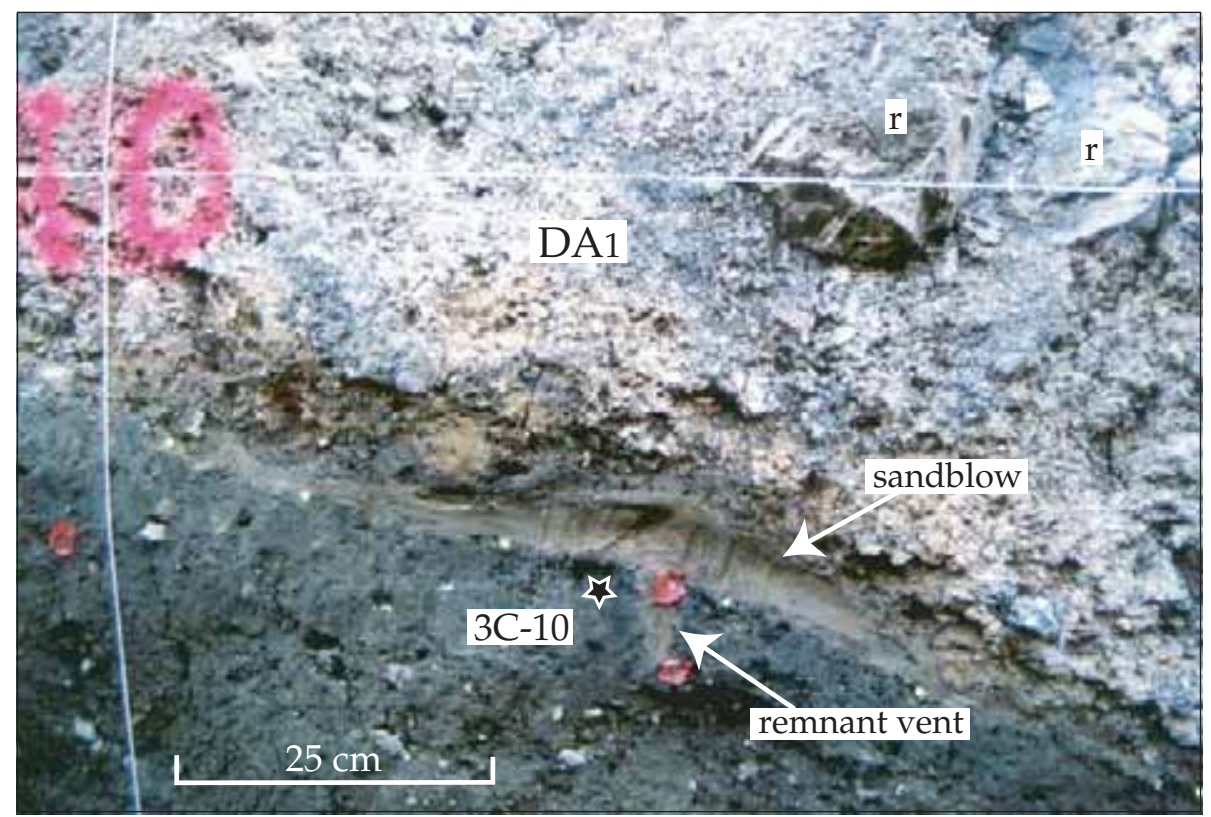

Fig. 10. Photo of trench stratigraphy at metre 10, including sandblow deposit and remnant vent (arrowed), overlying the lateral equivalent unit to paleosol $\left(\mathrm{P}_{1}\right)$, the top of which forms the event horizon for Event II, and the overlying debris avalanche deposit, $\mathrm{DA}_{1}$.

breccias $\left(\mathrm{DA}_{1}, \mathrm{DA}_{2}\right)$, interpreted as debris avalanche deposits. Incorporated within these deposits are ripped up blocks of the underlying soil horizons and chunky charcoal fragments. In addition, at the base and toward the toe of these deposits are pockets of well-sorted granular gravels, and deformed obliquely-stacked soil units, respectively. The former are interpreted as debris avalanche surge deposits, while the latter are likely to be «bulldozed» toe deposits related to the avalanches stripping off the soil cover. Clast range in size from $1 \mathrm{~m}$ (soil rip-ups) to $50 \mathrm{~cm}$ (rock clasts), to as little as sand size. The DA deposits are densely-packed but have little definable matrix material. This list of features is indicative of an en masse style of deposition or emplacement. It is likely that these deposits emanated from the greywacke hillslopes above the trench. Unit $\mathrm{DA}_{1}$ probably correlates to the cobbly substrate to the modern soil of Trench 1, the latter being a thin, distal equivalent of $\mathrm{DA}_{1}$.
Separating $\mathrm{DA}_{1}$ and $\mathrm{DA}_{2}$ is a grey-brown silt loam with mottles toward its base and a sharp upper contact. We interpret this unit to be a paleosol (Paleosol 2, $\mathrm{P}_{2}$ ) that was buried by the second avalanche. Included as part of the Debris Avalanche Package below $\mathrm{DA}_{1}$ is a dome-shaped medium sand deposit with remnant vent, considered to be a preserved liquefaction sand volcano (fig. 10). No continuous feeder dike that terminated downward into a source was exposed. However, a source (sand) layer for the sandblow was discovered $c a .1 .5 \mathrm{~m}$ below it during later deepening of the trench.

The Debris Fan (DF) Package represents deposits at the north end of the trench above $\mathrm{DA}_{2}$, related to the debris fan that extends a lobe south toward the scarp (fig. 5). Unlike the debris avalanche units, the Debris Fan units are generally well-bedded and sorted, clast-supported gravels and are therefore clearly of different origin. The DF gravels have a sheeted, non-waterlain fabric and are therefore consid- 
ered to be of debris fan origin. At the base of the DF Package is an unbedded fine-grained clastic unit limited in its deposition to a small «backbasin» on top of debris avalanche $\mathrm{DA}_{2}$. Two samples (17D and 1F-18), discussed below, were taken from the upper surface of $\mathrm{DA}_{2}$ and overlying fine-grained unit. The Modern Soil (MS) overlies the Scarp, Debris Avalanche, and Debris Fan Packages. In the middle part of the trench it is a weakly-developed soil with a gravely A horizon and minor development of a nutty soil texture. From metres 12 to 7, the three soils (including $\mathrm{P}_{1}$ and $\mathrm{P}_{2}$ ) converge toward the fault scarp where, albeit faulted, they appear to merge to form one composite soil profile on the scarp (figs. 7a,b and 9a-d).

\subsection{Faulting}

The geologic record in Trench 2 has been progressively stripped of units and retro-deformed in fig. 9a-d to clearly demonstrate the sequence of events. The dominant mode of displacement (dextral) cannot be quantitatively accounted for in the trench. However, there is evidence of thickness changes in units and juxtaposition of dissimilar units across faults. The zone of faulting in T2 covers a similar width $(\sim 7 \mathrm{~m})$ to that seen in Trench 1 (fig. 7a), where many more events have taken place over a longer timeframe. Paleoearthquake events in Trench 2 are recognised on the basis of both stratigraphic and structural evidence.

The Most Recent Event (MRE) faulting appears to be completely buried by instantaneous deposition of debris avalanche $\mathrm{DA}_{2}$ (fig. $9 b) . \mathrm{DA}_{2}$ overlies Paleosol 2, which is faulted from metres $12-14$ by faults A-C. The apparent vertical separation across these three faults is ca. $25 \mathrm{~cm}$. Horizontal offset is implied from the difference in thickness of Unit $\mathrm{DA}_{1}$ and $\mathrm{P}_{2}$ across these faults. $\mathrm{DA}_{2}$ and the modern soil have buried and overlie the surface rupture, creating the impression of a flat unfaulted surface in the rift zone (fig. 9b). The rumpled form of the paleosol $\left(\mathrm{P}_{2}\right)$ seen in the trench wall is mirrored in the shape of the preserved scarp from the most recent event, immediately west of the trench where no debris avalanche material was deposited. At metre-7, at the base of the scarp where the geomorphic expression of faulting is greatest, $\mathrm{P}_{2}$ was also faulted during the MRE on fault $G$ with small vertical separation across it $(<5 \mathrm{~cm})$. We infer that the debris avalanche $\mathrm{DA}_{2}$ was initiated due to strong shaking and ground motions in the hillslope above the trench site. The deposit itself is very poorlysorted, has a brecciated texture, and shows evidence of surge facies and toe deposits at its base and front. While the model of burial of the event horizon is equivocal, the faulting itself is not, and there does not appear to be better reason for the presence of such a deposit at that stratigraphic level.

The best evidence for Event II is faulting on fault $\mathrm{F}$ at the main scarp that cuts Paleosol 1 and terminates at its top, not displacing the surge or toe deposits of $\mathrm{DA}_{1}$. Fault $\mathrm{F}$ also juxtaposes paleosol $\mathrm{P}_{1}$ against sheared bedrock (fig. $9 \mathrm{c}$ ). The penultimate event is also implied by an apparent increase in vertical separation on fault $\mathrm{C}$ from $25 \mathrm{~cm}$ (offset of $\mathrm{P}_{2}$ ) to $55 \mathrm{~cm}$ (offset of $\mathrm{CF}_{\mathrm{b}}$ ) for two events. However, we recognise that some of the observed vertical must be the result of strike-slip separation on $\mathrm{DA}_{1}$. The liquefaction sandblow deposit (fig. 10) and Debris Avalanche deposit $\left(\mathrm{DA}_{1}\right)$ provide additional evidence for the penultimate event, as punctuated deposits associated with the strong ground motions of a surface-rupturing earthquake event. Both of these deposits have a clear, instantaneous relationship with each other and the underlying paleosol (former ground surface). This model requires that the paleosol developed in the interseismic period. During the earthquake a liquefaction fountain ejected sand onto the paleosol surface, sourced from a sand layer discovered below the floor of the trench (fig. 9d). Temporally, this deposit was almost immediately overlain by the debris avalanche, $\mathrm{DA}_{1}$.

Further evidence for a third paleoseismic event is recorded at the bottom of the trench between metres 7 to 8 , where faults D and E cut the lower Channel Fill Package deposits $\left(\mathrm{CF}_{\mathrm{a}}\right)$, juxtaposing those units against bedrock. The timing of these three events is discussed below with respect to the ages of radiocarbon samples and the record in Trench 1. Additionally, there are many mapped shears within the bedrock 
scarp. Most of these have no impact upon the recent paleoearthquake story. However, fault $\mathrm{H}$ at metre-5 does appear to cut the base of the colluvial scarp deposits and is therefore likely to have ruptured during one of the recent events.

\subsection{Radiocarbon dates}

Trench 2 contained an abundance of large charcoal fragments that were recovered from several units. Five samples were submitted to the Rafter Radiocarbon Lab to determine radiocarbon age dates (table I). They were selected (blind) in order to bracket the time both before and after the two most recent surface-rupturing earthquake events. Four of these age dates were young $(<1000$ years old $)$, while the remaining date, on sample $1 \mathrm{~F}-18$ from the top surface of $\mathrm{DA}_{2}$, was anomalously old. On closer examination this sample had the appearance of lignitic carbon. The means of the four young dates fall within $\sim 275$ radiocarbon years of each other, but show stratigraphic disorder in their ages, i.e. the oldest is highest and lowest is youngest (fig. 6). However, when calendar-calibrated these four dates are indistinguishable in their calibrated age ranges (fig. 11a,b).

Charcoal is not generally formed in situ and in this case was probably derived from a common source in the forested hillslope environments above the trench site. It seems likely that the charcoal fragments came from mature, burned trees that have been resident near the ground surface for long periods of time. The reworked charcoal is inferred to have been deposited episodically in the small rift zone basin at the trench site. The four dates themselves may reflect the age of any part of any burned tree above the site and we interpret the stratigraphic disorder of charcoal $\mathrm{C}^{14}$ dates obtained accordingly. Those associated with the debris avalanche deposits were instantaneously included and transported into place, but do occur in deposits separated by significant time, i.e. separated by a paleosol. However, it is clear that the lowest sample (3C-10) was deposited first and yielded the youngest uncalibrated radiocarbon age result. Therefore it provides a
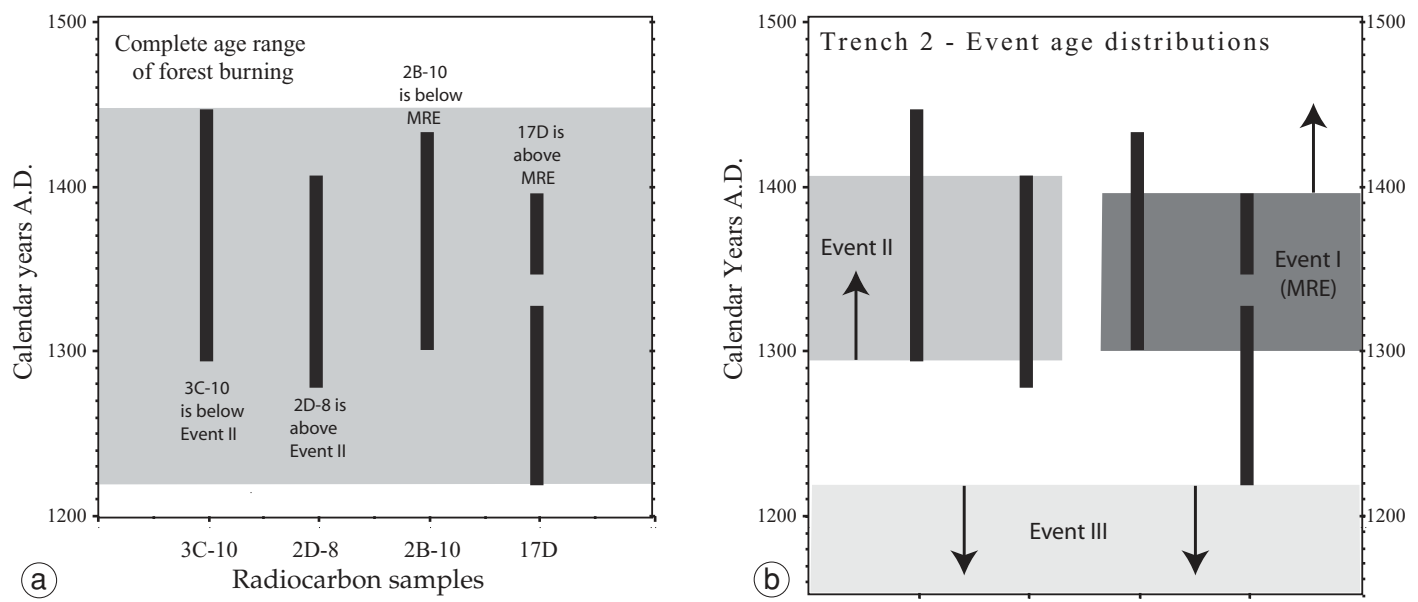

Fig. 11a,b. Two-sigma calibrated age ranges for the four young radiocarbon dates on charcoal from Trench 2 and their implications: a) the complete range of these samples represents wood probably burned in a single fire event; b) samples from above and below both Events I and II indicate that their event age distributions are indistinguishable. Despite their overlap, these ranges can be used to define the likely bounds of Events II and III. 
maximum age for the timing of the two paleoseismic events that followed its deposition.

As discussed above, the four radiocarbon dates have overlapping, indistinguishable calibrated age ranges at the $2 \sigma$ limit (fig. $11 \mathrm{a}, \mathrm{b}$ ). Together with the abundance of charcoal of the same age in units deposited by both gradual and en masse means, these results suggest a single burn event of an old forest between 1295 and 1450 A.D., that may be the result of Polynesian expansion into Northern South Island in preEuropean times.

\section{Discussion}

\subsection{Slip rate of the Conway Segment}

A new independent slip rate is determined here from the geomorphic offset of the abandoned paleochannel of Urquhart Stream in concert with the age of associated fan deposits (fig. 5 ). One end of the offset, defined by piercing point $\mathbf{P}$, comes from projecting the valley axis at the head of the fan where the stream emerges from the mountain front, to the fault. This assumes that if the Hope Fault were not deflecting it, Urquhart Stream would flow straight across (perpendicular to) the mountain front. $\mathbf{P}$ is not located in the centre of the modern channel. $\mathbf{P}^{*}$ is the other piercing point and is related to the outlet of the former stream course as it crosses the fault and cuts through the scarp. $\mathbf{P}^{*}$ is the projection back to the fault of the straightened downvalley stretch of the former Urquhart Stream beyond the scarp. The distance $\mathbf{P} \mathbf{P}^{*}$ comes from progressive dextral displacement along the Hope Fault related to the course and deflection of Urquhart Stream prior to its current incision. PP* has a value of $115 \mathrm{~m}$ and an associated error of $\pm 15 \mathrm{~m}$. The uncertainty comes from the combination of the position of the modern channel and the outlet of the abandoned channel.

The age of deposits related to this displacement is based on radiocarbon date Fs1 (table I) taken from charcoal in a basal silt layer in Trench 1 (fig. 6). This represents the oldest exposed unit containing datable material. Because we did not expose the base of the fan sequence, we must consider this date to reflect a minimum age for fan deposition within the fault furrow related to the stream deflection. Therefore, the slip rate derived from this calculation is closer to a maximum rate. The combination of displacement and age for the paleochannel of Urquhart Stream produces a dextral slip rate for the Conway Segment at this site of 18.9-26.8 mm/yr (rounded to $23 \pm 4 \mathrm{~mm} / \mathrm{yr}$ ). We suspect that the actual slip rate should fall inside this maximum slip rate range.

This new data can be used to better define the geologic slip rate for the Conway Segment. Our results compare favourably with other slip rate studies on the Conway Segment, such as the rate of $18 \pm 8 \mathrm{~mm} / \mathrm{yr}$ derived from Hossack Station at the western end of the Conway Segment (McMorran, 1991). Dextral slip rates of ca. 28 and $33 \pm 1.5 \mathrm{~mm} / \mathrm{yr}$ have been determined from offset terraces at Sawyers Creek, $3 \mathrm{~km}$ east of this site (Van Dissen, 1989; Bull, 1991). The weathering rind ages associated with this offset were re-analysed by Pope (1994) using the calibration criteria of McSaveney (1992), yielding slip rates in the range 31-55 $\mathrm{mm} / \mathrm{yr}$. Clearly, the upper end of this range is extreme, as it is greater than the whole plate motion rate for the entire MFZ (Bourne et al., 1994; De Mets et al., 1994).

In addition to our new results and using the same method of offset geomorphology and dated deposits in trenches, we recognise a comparable value for a young offset fan at the Clarence Reserve releasing step-over (Pope, 1994; Campbell, 2001), $2 \mathrm{~km}$ to the east of our site. This site yields a slip rate of ca. 25 $\mathrm{mm} / \mathrm{yr}$, implying that locally our new slip rate is a valid result. The greater weight of evidence, particularly from features dated by radiocarbon methods implies that the slip rate range for the Conway Segment is likely to be somewhat lower estimates than made using weathering rind data, in accordance with our new results.

\subsection{Slip per event and recurrence interval}

The average slip per event, or Single Event Displacement (SED) mapped from offset ridges, terrace risers, and channels at 9 localities be- 
tween Greenburn Stream and Sawyers Creek by Pope (1994) is 5-6 m. This value is comparable to the $6 \pm 2 \mathrm{~m}$ estimated by Bull (1991) farther west. At Urquhart Stream, where the slip rate is calculated, displacements from offset features are measured at $3.4,4.9 \pm 0.2$, and $10.4 \pm 0.2 \mathrm{~m}$ No new evaluation of SED has been undertaken, therefore we apply the pre-existing dataset of Pope (1994) to the Greenburn Stream site. The Recurrence Interval (RI) for this site may then be calculated independent of event ages using the slip rate $(23 \pm 4 \mathrm{~mm} / \mathrm{yr})$ and SED range of 5-6 m. This yields an average RI of 185-263 years. This range overlaps, but is generally higher than (longer RI), the recurrence range for the neighbouring Hope River segment (81-220 years) (Cowan and McGlone, 1991), the range calculated by Pope (1994) from data collected locally, and recent estimates for the Conway Segment (120-300 years) provided by Pettinga et al. (1998, 2001). A caveat of our RI range is that it is calculated from a lower SED range and a slip rate tending toward the maximum. However, as shown in the next section, they compare favourably with the stratigraphic and chronologic evidence for large earthquakes at this site.

Using a variation of the $v=d / t$ equation we can use results from the Greenburn Stream site to develop an independent test of our RI. The equation we use is

$$
R I=t_{1}=t_{n} / n ; \text { where } n=d_{n} / d_{1} .
$$

The total displacement $\left(d_{n}\right)$ or deflection of Urquhart Stream at the site is $115 \pm 15 \mathrm{~m}$. At 5 to $6 \mathrm{~m}$ of displacement per event (i.e. $d_{1}$ ), between 17-26 large seismic events $(n)$ are required to achieve the displacement, $d_{n}$. If these events occurred over a period of time $\left(t_{n}\right)$ represented by the age of the fan deposits in Trench 1 (sample Fs1), then the average recurrence for these events $\left(t_{1}\right)$ is 179-311 years, consistent with the range we calculated (185-263 years) above using the slip rate $(v)$. Combining these two techniques we present a value of 180-310 years for the recurrence interval from the Greenburn Stream site. Given that only one piece (Hope River Segment) of the Hope Fault has ruptured during the historic period $(\sim 160$ years), we favour our results, which suggest a longer RI for at least the Conway Segment of the Hope Fault.

\subsection{Timing of the last three large seismic events}

We recognise and can place some temporal constraints on each of the last three paleoearthquakes on the Conway segment of the Hope Fault from the Greenburn Stream site. Constraints come from the four young radiocarbon dates in T2, the weathering rind data (Pope, 1994), and stratigraphic correlation to T1. Event III is recognised to have occurred during deposition of Packages $\mathrm{C}$ and $\mathrm{CF}$ in Trenches 1 and 2, respectively (fig. 7a,b). This is observed from the faulting that caused thickening or juxtaposition of channel $\mathrm{C}_{1}$ in $\mathrm{T} 1$ and faults penetrating to the top of $\mathrm{CF}_{\mathrm{a}}$ in $\mathrm{T} 2$ (fig. 9d). If $\mathrm{C}_{2}$ and $\mathrm{CF}_{\mathrm{b}}$ were not faulted during Event III then its age is older than that of sample $3 \mathrm{C}-10$ (1295-1405 A.D.). However, if we consider the $2 \sigma$ range of sample 17D then this event may be older (fig. 11a,b). That is, if 17D represents forest material burned at the same time as the other samples (fig. 11a) and is the oldest material above Event III, then that event must have occurred prior to 1220 A.D. No reasonable lower constraint can be placed on this event at this time, though stratigraphically it occurred within the $\mathrm{C}$ and $\mathrm{CF}$ Packages. This record of faulting indicates that three paleoearthquakes have occurred since a fundamental change in the style of sedimentation observed in Trench 1, from an outwash fan style with paleodirections perpendicular to the scarp (F, MF, and UF Packages), to scarp-parallel drainage in small constricted channels ( $\mathrm{C}$ and CF Packages). This change may reflect the timing of fan abandonment and Urquhart Stream incision.

What can we deduce about the timing and recurrence of the MRE (Event I) and Event II? If we consider only the radiocarbon age data (the samples above and below each event), then Events I and II are indistinguishable due to their overlapping age ranges (fig. 11b). The two most recent events have been recognised as discreet events in both trenches based on upward termi- 
nations of faults and faulted horizons, supported by stratigraphic correlation, and a model of instantaneous event deposition of debris avalanche deposits and a liquefaction sandblow. First, we must clarify the timing of Event II. The maximum age of Event II is best constrained by sample 3C-10 (the youngest and lowest of 4 dates) to be younger than $548 \pm 60$ $\mathrm{C}^{14}$ years BP. Unlike the other three young samples, 3C-10 was deposited in the organic silt adjacent to paleosol $\mathrm{P}_{1}$ and was faulted during Event II. When calendar calibrated to the $2 \sigma$ level, this age becomes 1295-1405 A.D. (504656 years BP). Therefore, even though the four dated samples are likely to have a common source we can isolate sample 3C-10 as the one that provides information concerning the age of that event horizon. Event II must be younger than 1295 A.D. The maximum age is also dependent upon the length and timing of the previous interseismic period, i.e. the period between Events III and II. We recognise that only a few units were deposited after Event III and before the beginning of soil development (paleosol $\mathrm{P}_{1}$ ) on the $\mathrm{CF}$ Package. We argue below that such soil development requires a minimum of 160 years.

Clearly, two paleoseismic events have occurred on the Conway Segment since 1295 A.D., and prior to the historic period, i.e. 1840 A.D. Is it possible that the most recent (I) and penultimate (II) events are broadly spaced and occurred close to the edges of the recurrence range? Or, were they closely spaced (clustered) in time, as suggested by Bull (1998)? As discussed, the four samples that we attempted to bracket the events with have indistinguishable age ranges at the $2 \sigma$ level. Therefore, they cannot be used to uniquely date the paleoearthquakes themselves, i.e. the Event I and II ranges in fig. $11 \mathrm{a}, \mathrm{b}$ reflect the age of a burning event rather than two clustered earthquakes.

However, evidence for these earthquakes being spaced by a significant interseismic period is gleaned from the history of soil development at the site. Three soils (including MS) exist in the middle part of Trench 2 (metres 715 ), which each formerly merged with the soil on the scarp. They $\left(\mathrm{P}_{1}\right.$ and $\left.\mathrm{P}_{2}\right)$ formed the ground surface prior to large earthquakes and were buried by earthquake-induced debris avalanches. Interestingly, all three soils have been the main time units that have developed over most of the last 3 interseismic periods, and therefore themselves, represent the interseismic period. The modern soil has been forming for a minimum of $\sim 163$ years (i.e. since 1840). It is weakly developed with little fine material included from fluvial or aeolian input, and little clay accumulation. Paleosol 2 is a moderatelydeveloped soil with a thick accumulation of fines and mottled B horizon. It formed between the MRE and penultimate earthquakes. $\mathrm{Pa}$ leosol 1 is a dark, moderately-developed soil formed on a fine-grained fill deposit against the paleoscarp. It grades away from the scarp into an organic-rich pond deposit (fig. 9a-d). Both of these paleosols required significant time to develop before being buried by debris avalanche deposits, possibly a factor of 2 times more than is seen in the modern soil. This amount of time (160-320 years) is equivalent to the recurrence interval calculated previously.

Furthermore, soil accumulation at Trench 1 was probably not interrupted by the deposition of scattered blocks of sandstone across its surface, $c f$. the complete burial of the soil $\mathrm{P}_{2}$ by debris avalanche $\mathrm{DA}_{2}$ in T2 (fig. 9a-d). Therefore, in terms of time, the modern soil in T1 probably represents the elapsed time required to form both Paleosol 2 and the MS in T2. In addition, the cobbles on which the MS of T1 formed are equivalent in age to $\mathrm{DA}_{1}$ in Trench 2 , and were deposited en masse following Event II. These statements bear on the age bracketing of the MRE. The clasts on the surface of the modern soil adjacent to Trench 1 are dated using the weathering rind technique at $220 \pm 60$ years, while the modern soil in T1 appears to be faulted. This evidence points to the age of the MRE being equivalent to that of the weathering rind surface age, i.e. $220 \pm 60$ years, or about 1780 A.D. \pm 60 years. Given the uncertainties that may exist in the surface age, the stratigraphic correlation between trenches, soil history and the punctuated landscape change model, this is an impressive result.

By constraining the interval across which the MRE occurred in concert with the soil history, we yield additional knowledge concerning 
the minimum age of Event II. We argue that Paleosol 2 took much more time to form than the modern soil, based on the accumulation of fines and development of mottling (160-320 years). We assert that the spacing of Events I and II (interseismic period) is probably at the upper end of our recurrence range. This pushes the minimum age of Event II back toward the age of the forest burning, or more reasonably to within the period thereafter.

\subsection{Implications of the timing of the MRE}

The results of this work argue for a young, pre-European surface-rupturing earthquake (1780 A.D. \pm 60 years) on the Conway Segment of the Hope Fault. We consider that this range gives the best estimate possible of the MRE, while giving due credence to the inherent uncertainties. At the upper end of this range (1840 A.D.), the historic period is encountered; thereafter it is known that no surface-rupturing event exists for the Conway Segment. At the lower end of the range, an equivalent uncertainty is accounted for, representing that which stems from our stratigraphic, dating, or deformation argument. One implication of this result and the recurrence data is that we are beginning to approach, or have already entered, the lower limit of the recurrence range for the Conway Segment.

How does this MRE age compare with previous studies? No previous trench (on-fault) studies have produced event timing for the MRE (see McMorran, 1991; Pope, 1994). The only other MRE information comes from lichenometric studies of earthquake-induced rockfall throughout the Kaikoura ranges (Bull, 1991, 1998; Bull and Brandon, 1998). Lichen re-colonisation has been used as a proxy for very strong earthquake shaking. However, these results are off-fault or indirect paleoseismic indicators and so are therefore not necessarily associated with large earthquakes. Bull (1998) identifies two surface-rupturing events attributed to the Conway segment that occur within the uncertainty range of our results, at 1768 A.D. and at 1832 A.D. Our evidence supports Bull's assertion that large shaking events have occurred in the Kaikoura ranges in the recent past, immediately prior to European settlement of New Zealand. However, our trenches show clear evidence for only one event over this time period on the Conway Segment, with a significant time break (equivalent to the calculated RI) between the MRE and penultimate event, shown by the development of soil (Paleosol 2) at the site. We cannot separate or confirm the reliability of the 1768 or 1832 A.D. events, though we consider it possible that the MRE observed at Greenburn Stream is one of these events. Other fault segments in the region, e.g., Kowhai Fault (fig. 3), could be the source of a separate young, rockfall-inducing event. In future, more historical data from Kaikoura, an early New Zealand whaling and sealing settlement may help confirm the age of the most recent events in the Southeastern Marlborough Fault Zone.

\section{Summary}

i) Two trenches were opened near Greenburn Stream on the Conway Segment of the Hope Fault. These trenches were dug through ponded fill deposits against an uphill-facing scarp next to Urquhart Stream.

ii) Trench 1 intercepted alluvial fan deposits up to $c a$. 5000 years old, and showed evidence for multiple earthquake events. Data from this trench was used to develop an independent dextral slip rate of $23 \pm 4 \mathrm{~mm} / \mathrm{yr}$.

iii) Trench 2 intercepted a fill of younger deposits and showed evidence for the last 3 paleo-earthquakes. The two youngest events are constrained by radiocarbon dates and the historic period to have occurred between 12951840 A.D. Event III probably occurred prior to 1220 A.D.

iv) The age of the most recent event could be constrained between 1720-1840 A.D. given that the modern soil of Trench 1 is faulted and that the cobbly surface deposit on it is dated at $220 \pm 60$ years BP. Significant time exists between each of these three events as observed in the record of soil development.

v) The single event displacement based on offset features near Urquhart Stream is 5-6 m. 
In combination with the calculated slip rate, age, and total displacement, the SED produces a recurrence interval of 180-310 years.

\section{Acknowledgements}

The authors wish to thank Murray Urquhart (Hawks Hill Station) for permission to access his farm - you are now immortalised through the naming of this stream. Thanks also to the ILP participants for review in the field. A special thanks for assistance from ILP and the ILP Conference Organisers for including the idea for this project. We thank Tim Dawson and Ramon Arrowsmith for thoughtful review comments. We also thank Mark Stirling and Nicola Litchfield of GNS for internal review comments and discussion that significantly improved this paper. This work was funded by FRST PostDoctoral Fellowship CO5903, FRST Subduction Geology 43014300 and South Island Active Faults 41020411, ILP Conference support, and University of Canterbury Research Grant U6451.

\section{REFERENCES}

Anderson, H. and T. WebB (1994): New Zealand seismicity: patterns revealed by the upgraded National Seismic Network, N. Z. J. Geol. Geophys., 37, 477-493.

Anderson, H., T. WebB and J.A. JaCKSON (1993): Focal mechanisms of large earthquakes in the South Island of New Zealand: implications for the accommodation of the Pacific-Australia Plate motion, Geophys. J. Int., 115, 1032-1054.

BARNES, P.M. and J.C. AUDRU (1999): Recognition of active strike-slip faulting from high-resolution marine seismic reflection profiles: Eastern Marlborough Fault System, New Zealand, Geol. Soc. Am. Bull., 111, 538559.

Berryman, K.R., S. Beanland, A.F. CoOper, H.N. CutTen, R.J. Norris and P.R. Wood (1992): The Alpine Fault, New Zealand: variation in Quaternary structural style and geomorphic expression, Ann. Tectonicae, VI, 126-163.

BibBy, H.M. (1976): Crustal strain across the Marlborough Faults, New Zealand. N. Z. J. Geol. Geophys., 19, 407-425.

Bourne, S.J., T. Arnadottir, J. Beavan, D.J. Darby, P.C. England, B. PARsons, R.I. WalcotT and P.R. WoOD (1998): Crustal deformation of the Marlborough Fault Zone in the South Island of New Zealand: geodetic constraints over the interval 1982-1994, J. Geophys. Res., 103, 30,147-30,165.
Bull, W.B. (1991): Geomorphic Responses to Climate Change (Oxford University Press, New York), pp. 326.

BuLL, W.B. (1998): Lichenometry: a new way of dating and locating prehistorical earthquakes, in Dating and Earthquakes: Review of Quaternary Geochronology and its Application to Paleoseismology, U.S. Nuclear Regulatory Commission volume, NUREG/CR-5562.

Bull, W.B. and M.T. BRANDON (1998): Lichen dating of earthquake-generated regional rockfall events, Southern Alps, New Zealand, Geol. Soc. Am. Bull., 110, 60-84.

CAMPBELl, J.K. (1973): Displacement data from the Alpine Fault at Lake Rotoiti and its relevance to glacial chronology and the tempo of tectonism, in Proceedings of the IX Congress INQUA (International Union for Quaternary Research), Abstracts volume, 57-58.

CAMpBell, J. (2001): The Hope Fault: field trip guide, in International Lithosphere Program, Ten Years in Paleoseismology in the ILP, Kaikoura, New Zealand, December 2001, pp. 31

CowAN, H.A. (1989): An evaluation of the Late Quaternary displacements and seismic hazard associated with the Hope and Kakapo faults, Amuri District, North Canterbury, Unpublished M.Sc. Engineering Geology Thesis (lodged in the Library, University of Canterbury), pp. 239.

CowAN, H.A. (1990): Late Quaternary displacements on the Hope Fault at Glynn Wye, North Canterbury, N. Z. J. Geol. Geophys., 33, 285-293.

CowAN, H.A. (1991): The North Canterbury earthquake of September 1, 1888, J. R. Soc. N. Z., 21, 1-12.

Cowan, H.A. and M.S. McGlone (1991): Late Holocene displacements and characteristic earthquakes on the Hope River Segment of the Hope Fault, New Zealand. J. R. Soc. N. Z., 21, 373-384.

DeMets, C., R.G. Gordon, D.F. Argus and S. Stein (1994): Effect of recent revisions to the geomagnetic reversal time scale on estimates of current plate motions, Geophys. Res. Lett., 21, 2191-2194.

Eusden, J.D., J.R. Pettinga and J.K. Campbell (2000): Structural evolution and landscape development of a transpressive duplex on the Hope Fault, North Canterbury, New Zealand, N. Z. J. Geol. Geophys., 43, 391-404.

Freund, R. (1971): The Hope Fault: a strike-slip fault in New Zealand, N. Z. Geol. Surv. Bull., 86, p. 49.

GrAPES, R., T. LiTTLE and G. DownEs (1998): Rupturing of the Awatere Fault during the 1848 October 16 Marlborough earthquake, New Zealand: historical and present day evidence, N. Z. J. Geol. Geophys., 41, 387-400.

HARDY, E.F. and H.W. Wellman (1984): The Alpine, Wairau and Hope faults, Victoria University of Wellington, Geology Dept. Publication, 27.

HolT, W.E. and A.J. HAINES (1995): The kinematics of northern South Island, New Zealand, determined from geologic strain rates, J. Geophys. Res., 100, 17,99118010.

KIECKHEFER, R.M. (1979): Sheets M31D, N31A, N31C, and parts of M32A and M32B Leader Dale (1st edition), Sheets N31B and N31D Dillon (1st edition), in Late Ouaternary Tectonic Map of New Zealand 1:50000 (Department of Scientific and Industrial Research, Wellington, New Zealand), 3 maps and text, pp. 28. 
KNUEPFER, P.L.K. (1992): Temporal variations in latest Quaternary slip across the Australian-Pacific plate boundary, northeastern South Island, New Zealand, Tectonics, 11, 449-464.

LANGRIDGE, R.M. (2003): Holocene displacement and slip rate for the Hurunui section of the Hope Fault, South Island, New Zealand, N. Z. J. Geol. Geophys. (in press).

LENSEN, G. (1968): Analysis of progressive fault displacements during downcutting at the Branch River terraces, South Island, Geol. Soc. Am. Bull., 79, 545-566.

McCAlPin, J.P. (1996): Tectonic geomorphology and Holocene paleoseismicity of the Molesworth section of the Awatere Fault, South Island, New Zealand, N. Z. J. Geol. Geophys., 39, 33-50.

MCKAY, A. (1890): On the earthquakes of September 1888 , in the Amuri and Marlborough Districts of the South Island, N. Z. Geol. Surv. Rep. Geol. Explor., 20, 1-16.

McMorran, T.J. (1991): The Hope Fault at Hossack Station east of Hanmer Basin, North Canterbury, Unpublished M.Sc. Thesis (lodged in the University of Canterbury Library, Christchurch), pp. 239.

MCSAVEnEY, M.J. (1992): A manual for weathering-rind dating for sandstone clasts of the Torlesse Supergroup, Institute of Geological and Nuclear Sciences Report 92/4 (Lower Hutt, New Zealand, Institute of Geological and Nuclear Sciences Ltd.), pp. 52.

Pettinga, J.R., C.G. Chamberlain, M.D. Yetton, R.J. VAN DisSEN and G. Downes (1998): Earthquake source identification and characterisation: stage 1 (Part A) earthquake hazard and risk assessment study, Canterbury Regional Council CRC, Publication No. U98/10, pp. 121 and 6 appendices.

Pettinga, J.R., M.D. Yetton, R.J. Van Dissen and G. DOWNES (2001): Earthquake source identification and characterisation for the Canterbury region, South
Island, New Zealand, Bull. N. Z. Soc. Earthquake Eng., 34, 282-317.

Pope, J.G. (1994): Secondary structures, Holocene displacements and paleoseismicity of the Conway Segment of the Hope Fault, Greenburn Stream to Sawyers Creek, Unpublished B.Sc. (Hons.) Project (Geological Sciences Library, University of Canterbury, Christchurch, New Zealand).

REYNERS, M. and H. CowAN (1993): The transition from subduction to continental collision: crustal structure in the North Canterbury region, New Zealand, Geophys. J. Int., 115, 1124-1136.

Simpson, R.J. (1995): The Seaward segment of the Hope Fault, Seaward Kaikoura ranges, Southeast Marlborough, Unpublished B.Sc. (Hons.) Project (Geological Sciences Library, University of Canterbury).

Stuiver, M., P.J. Reimer, E. BArd, J.W. Beck, G.S. Burr, K.A. Hughen, B. Kromer, F.G. McCormac, J. van DER Plicht and M. SPURK (1998): INTCAL98_14C: Atmospheric delta ${ }^{14} \mathrm{C}$ and radiocarbon ages, Radiocarbon, 40, 1041-1083.

VAn Dissen, R. (1989): Late Quaternary faulting in the Kaikoura region, Southeastern Marlborough, New Zealand, Unpublished M.Sc. Thesis (Oregon State University, USA), pp. 72.

VAN Dissen, R. and R.S. Yeats (1991): Hope Fault, Jordan thrust, and uplift of the Seaward Kaikoura Range, New Zealand, Geology, 19, 393-396.

Wood, R.A., J.R. Pettinga, S. Bannister, G. Lamarche and T.J. McMorran (1994): Structure of the Hanmer Strike-slip Basin, Hope Fault, New Zealand, Geol. Soc. Am. Bull., 106, 1459-1473.

YeATs, R. and K.R. BERRYMAn (1987): South Island, New Zealand, and transverse ranges, California: a seismotectonic comparison, Tectonics, 6, 363-376. 
